\title{
Modelling and forecasting of the region's environmental indicators
}

\author{
Olena Ovchynnikova ${ }^{1, *}$, Olha Dupliak $^{1}$, and Olha Khan $^{2}$
}

${ }^{1}$ Khmelnytskyi National University, Department of Automated Systems and Modeling in Economics, Khmelnytskyi, 29016, Ukraine

${ }^{2}$ Khmelnytskyi secondary school No. 19 of the I-III degree named after academician Mykhailo Pavlovskyi, Khmelnytskyi, 29000, Ukraine

\begin{abstract}
The environmental situation in the Khmelnytskyi oblast has been analyzed, models and forecasts of indicators have been developed by methods of extrapolation, regression analysis and trend models, and the quality of forecasting has been estimated. Namely, the models of influence of selected factors on the environmental situation in the Khmelnytskyi oblast have been developed. One- and multifactorial regression models have been constructed, conclusions about the degree of influence of factors have been made. Trend models of indicators of the ecological situation in the region have been constructed. Estimates of pollutant emissions, indicators of the creation and disposal of hazardous waste have been developed using different forecasting methods. These calculations can be used to carry out activities aimed at protecting the environment.
\end{abstract}

As a result of human economic activity in the natural environment, non-typical substances are accumulated, with solid wastes (garbage) and chemical compounds that lead to environmental pollution among which. The main sources of pollution are airborne industrial enterprises and transport [1]. The formation of ecological consciousness and ecological culture should stand in the way of human attitude towards nature; this includes rational use of nature resources, severe control over emissions and exploitation of natural resources. Targeted integrated environmental programs are required to address environmental issues related to the proper protection of atmospheric air, water and land, with the utilization and disposal of waste [2].

Therefore, the study of environmental problems, modeling of the impact of economic costs on the disposal of hazardous wastes and the prediction of pollution indicators of the territory is relevant.

The purpose of this study is to provide a theoretical justification and practical implementation of existing approaches to the study, modeling and forecasting of environmental performance indicators by methods of economic and mathematical modeling. The current environmental situation on the territory of Ukraine can be generally described as tense. When studying the situation in the environment, the impact on it of different types of pollutants must be taken into account [3]. And, as a rule, they not only worsen the environment, but also adversely affect certain environmental systems and organs of the human body, which can lead to serious diseases (Table 1).

Sources of pollutants are varied, as well as numerous waste types and characteristics of their effects on the components of the biosphere (Table 2).

When determining the influence of harmful substances on a person, plant and animal organisms, the degree of pollution of the environment, the norms of quality are used [6], expressed in the maximum permissible concentrations (MPC) of harmful substances, the maximum permissible levels (MPL), the maximum permissible emissions (MPE), of the pollutant in different environments (Table 3).

Table 1. Impact of some pollutants on human health [4].

\begin{tabular}{|c|c|c|}
\hline Substance & Sources & Impacts on Health \\
\hline $\begin{array}{c}\text { Chemicals of } \\
\text { different classes }\end{array}$ & Use of pesticides & $\begin{array}{c}\text { carcinogenic, } \\
\text { mutagenic }\end{array}$ \\
\hline Surfactants & Use of detergents & allergies, dermatitis \\
\hline $\begin{array}{c}\text { Petrochemicals, } \\
\text { organic solvents }\end{array}$ & $\begin{array}{c}\text { Petroleum refining } \\
\text { and other industrial } \\
\text { processes }\end{array}$ & $\begin{array}{c}\text { headache, loss of } \\
\text { coordination, } \\
\text { carcinogenic impact, } \\
\text { bone marrow lesions }\end{array}$ \\
\hline Vinyl chlorides & $\begin{array}{c}\text { Production of } \\
\text { plastics, synthetic } \\
\text { films }\end{array}$ & $\begin{array}{c}\text { carcinogenic, } \\
\text { mutagenic }\end{array}$ \\
\hline Dioxins & $\begin{array}{c}\text { Waste processing, } \\
\text { pharmacological } \\
\text { productions }\end{array}$ & $\begin{array}{c}\text { carcinogenic, } \\
\text { mutagenic } \\
\text { dermatogenic }\end{array}$ \\
\hline $\mathrm{Heavy} \mathrm{metals:} \mathrm{Pb}$ & $\begin{array}{c}\text { Use of paints, motor } \\
\text { fuels }\end{array}$ & $\begin{array}{c}\text { neutroxidation, } \\
\text { mutagenic }\end{array}$ \\
\hline $\mathrm{Cd}$ & $\begin{array}{c}\text { Use of electronics, } \\
\text { brake and hydraulic } \\
\text { fluids, fluorescent } \\
\text { lamps }\end{array}$ & $\begin{array}{c}\text { carcinogenic, } \\
\text { mutagenic } \\
\text { dermatogenic }\end{array}$ \\
\hline $\begin{array}{c}\text { Production of } \\
\text { batteries, mineral } \\
\text { fertilizers }\end{array}$ & $\begin{array}{c}\text { carcinogenic, } \\
\text { mutagenic }\end{array}$ \\
\hline
\end{tabular}

World experience shows that with the aggravation of environmental problems and the deterioration of the environment, the centralized administrative systems of environmental management have been created and

\footnotetext{
* Corresponding author: veleslavaovch $@$ gmail.com
} 
strengthened in all developed market economies [7]. Today, the EU countries are combating incinerators that have outdated technologies and pollute the environment and have toxic residues. Instead, scientists propose to innovate [8]. The structure of waste recycling in different countries of the world is presented in Table 4.

Table 2. Sources of environmental emissions [5].

\begin{tabular}{|c|c|c|}
\hline Industry & Type of emissions & Harm \\
\hline $\begin{array}{l}\text { Coal, metal, } \\
\text { paper }\end{array}$ & $\begin{array}{c}\text { Emissions } \\
\text { containing sand } \\
\text { particles, rocks and } \\
\text { other mechanical } \\
\text { impurities } \\
\end{array}$ & $\begin{array}{l}\text { May disrupt natural } \\
\text { ecosystems, sanitation, } \\
\text { muddy bottoms and } \\
\text { shores }\end{array}$ \\
\hline $\begin{array}{l}\text { Mechanical } \\
\text { engineering } \\
\text { plants, } \\
\text { chemical } \\
\text { industry } \\
\text { enterprises }\end{array}$ & $\begin{array}{c}\text { Emissions from } \\
\text { neutralization and } \\
\text { sewage }\end{array}$ & $\begin{array}{l}\text { The environment is } \\
\text { polluted by heavy metal } \\
\text { salts, cyanides, acids, } \\
\text { toxic organic and } \\
\text { inorganic compounds }\end{array}$ \\
\hline $\begin{array}{l}\text { Mining, coal } \\
\text { mining, } \\
\text { tanneries }\end{array}$ & $\begin{array}{l}\text { Contamination } \\
\text { containing micro- } \\
\text { and macronutrients }\end{array}$ & $\begin{array}{l}\text { Contamination of the } \\
\text { environment with } \\
\text { excessive amounts of } \\
\text { micro- and } \\
\text { macronutrients, in some } \\
\text { cases pathogens }\end{array}$ \\
\hline $\begin{array}{l}\text { Alcohol, sugar, } \\
\text { starches and } \\
\text { other } \\
\text { enterprises }\end{array}$ & $\begin{array}{c}\text { Contamination } \\
\text { containing organic } \\
\text { compounds of } \\
\text { vegetable and } \\
\text { animal origin } \\
\end{array}$ & $\begin{array}{c}\text { Environmental } \\
\text { contamination by easily } \\
\text { decaying organic } \\
\text { compounds can cause } \\
\text { infectious diseases } \\
\end{array}$ \\
\hline
\end{tabular}

Table 3. Air pollution assessment criteria [6].

\begin{tabular}{|c|c|c|}
\hline $\begin{array}{c}\text { Contamination } \\
\text { level }\end{array}$ & Danger rate & $\begin{array}{c}\text { Percentage of excess } \\
\text { of MPLs }\end{array}$ \\
\hline Acceptable & Safe & 0 \\
\hline Unacceptable & Low Dangerous & $>0 \ldots 4$ \\
\hline Unacceptable & $\begin{array}{c}\text { Moderately } \\
\text { dangerous }\end{array}$ & $>4 \ldots 10$ \\
\hline Unacceptable & Dangerous & $>10 \ldots 25$ \\
\hline Unacceptable & $\begin{array}{c}\text { Extremely } \\
\text { Dangerous }\end{array}$ & $>25$ \\
\hline
\end{tabular}

Table 4. Waste recycling in different countries (data as of 2015).

\begin{tabular}{|l|c|c|c|c|c|}
\hline \multirow{2}{*}{ Countries } & Total number & \multicolumn{2}{|c|}{ Composting } & Burning, & Burial, \\
& of $\begin{array}{c}\text { tons } \\
\text { \%o }\end{array}$ & \% & mln t & \% & \\
\hline Denmark & 15,54 & 69 & 10,72 & 23 & 7 \\
\hline Belgium & 5,56 & 67 & 3,726 & 30 & 2 \\
\hline Germany & 48,85 & 63 & 30,77 & 33 & 1 \\
\hline Ireland & 2,58 & 42 & 1,084 & 43 & 57 \\
\hline Italy & 32,89 & 39 & 12,82 & 15 & 46 \\
\hline Norway & 9,36 & 33 & 3,09 & 30 & 16 \\
\hline Poland & 4,78 & 18 & 0,860 & 1 & 73 \\
\hline Portugal & 5,47 & 20 & 1,093 & 19 & 16 \\
\hline Spain & 31,19 & 39 & 12,16 & 7 & 54 \\
\hline Sweden & 4,33 & 48 & 2,08 & 51 & 1 \\
\hline
\end{tabular}

Regarding the situation in the Khmelnytskyi oblast, the studies have shown that during the last twenty years of observations there has been a general reduction of pollutant emissions into the atmosphere. However, the problem of recycling, storage and processing of industrial toxic and household waste is becoming more acute for the region. The total amount of waste generated and accumulated in the storage facilities of enterprises has increased over the last year.

The problem of increasing the volume of solid household waste is also compounded by the large volume of solid municipal waste that is generated by economic activity (Figure 1).

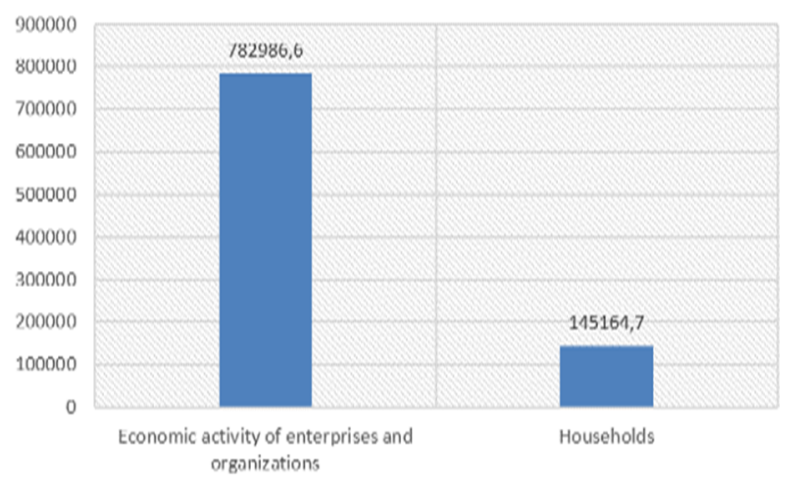

Fig. 1. Waste generation by type of economic activity and households in 2018 in the Khmelnytskiy regional [9].

The best disposal of waste should be the use of waste as secondary material or energy resources. Figure 2 shows the waste management in 2018 in Khmelnytskyi.

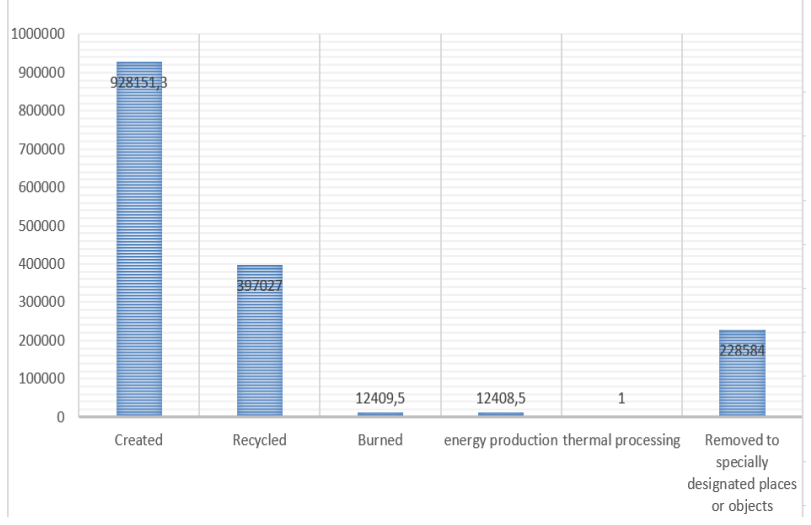

Fig. 2. Generation and management of I-IV waste classes by category of materials in 2018 .

Unfortunately, the volume of discharged contaminated wastewater into water bodies and the volume of pollutants have increased, but the designated areas and waste disposal facilities are increasing [10]. At the same time, attracting investment for environmental improvements requires identifying the sources of these investments, which is an important task. Therefore, environmental spending has increased in size and scope. The total amount of expenditures for environmental protection increased in 3.1 times during this period.

In the current conditions, the process of environmental research should be taken to a new level, in particular, it is necessary to develop new approaches to the application of econometric models and methods for forecasting indicators at the regional level. The following information was used to model the environmental situation of the Khmelnytskyi oblast (Table 5). 
Table 5. Baseline data for modeling of one-factor models [9].

\begin{tabular}{|c|c|c|c|c|}
\hline Years & $\begin{array}{c}\text { Emissions } \\
\text { of pollu- } \\
\text { tants, } \\
\text { thousand } \\
\text { tons }\end{array}$ & $\begin{array}{c}\text { Hazardous } \\
\text { wastes gene- } \\
\text { rated, } \mathbf{t}\end{array}$ & $\begin{array}{c}\text { Disposal of } \\
\text { hazardous } \\
\text { waste, } \mathbf{t}\end{array}$ & $\begin{array}{c}\text { Capital invest- } \\
\text { ments for envi- } \\
\text { ronmental pro- } \\
\text { tection, thou- } \\
\text { sand UAH }\end{array}$ \\
\hline & $\boldsymbol{Y}_{\mathbf{1}}$ & $\boldsymbol{Y}_{\mathbf{2}}$ & $\boldsymbol{Y}_{\mathbf{3}}$ & $\boldsymbol{x}$ \\
\hline 2006 & 57,9 & 1212,2 & 308 & 13547 \\
\hline 2007 & 87,5 & 1750,9 & 223,5 & 17627,1 \\
\hline 2008 & 92,1 & 1719,5 & 269,3 & 11584,2 \\
\hline 2009 & 81,5 & 1018,1 & 141,9 & 6744,8 \\
\hline 2010 & 83,8 & 1435346,7 & 260096 & 4358,1 \\
\hline 2011 & 83,5 & 1596823,7 & 288750,1 & 3853,1 \\
\hline 2012 & 79,7 & 1471062,1 & 526377,4 & 13915,6 \\
\hline 2013 & 80,7 & 1111642,5 & 492198,5 & 10164,6 \\
\hline 2014 & 79,2 & 1266163,8 & 305155,4 & 6816,9 \\
\hline 2015 & 75,5 & 960913,9 & 345947,4 & 19254,1 \\
\hline 2016 & 21,7 & 1299637,3 & 450101,4 & 36718,5 \\
\hline 2017 & 21,1 & 928151,3 & 397027 & 35863,5 \\
\hline
\end{tabular}

The resulting regression models are as follows:

$$
\begin{aligned}
& Y_{1}=99.32628-0.00193 x \\
& Y_{2}=829707.4+0.65921 x \\
& Y_{3}=166195.6+5.942164 x
\end{aligned}
$$

In modeling, only the obtained model (1) which is the impact of the amount of capital investment on environmental protection, showed a high correlation between the factor and the result.

Therefore, the models were obtained, of which only one is adequate, which confirms the relationship between capital investment and the pollutant emission rate. As the sign near the factor is negative, its increasing leads to a decrease in the resultant indicator, that is, the increase in capital investment for environmental protection reduces the amount of pollutants. Figure 3 presents the actual and calculated indicators by model (1).

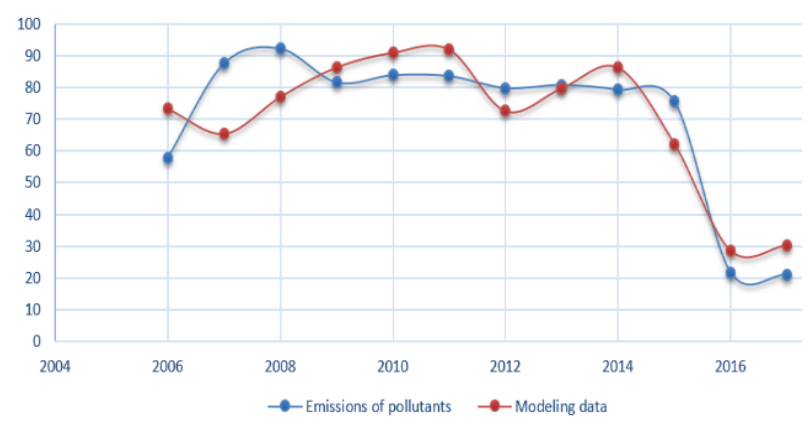

Fig. 3. Dynamics of actual and calculated indicators according to the model of the studied indicator "pollutant emissions".

The following multifactor models were built. As the indicators, the dynamics of the pollutant emissions were also taken, the hazardous waste generated and disposed. As for the factors, the economic indicators reflecting the costs of environmental protection, were taken (Figure 4).

The following models are based on performance indicators: $Y_{1}-$ Emissions of pollutants, thousand tons, $Y_{2}$ - Hazardous wastes, $Y_{3}$ - Disposal of hazardous waste, t. The influencing factors are: $x_{1}-$ atmospheric protection and climate change; $x_{2}$ - sewage treatment; $x_{3}$ - waste management; $x_{4}$ - protection and rehabilitation of soil, groundwater and surface water; $x_{5}-$ conservation of biodiversity and habitat; $x_{6}-$ other areas of environmental activity [8].

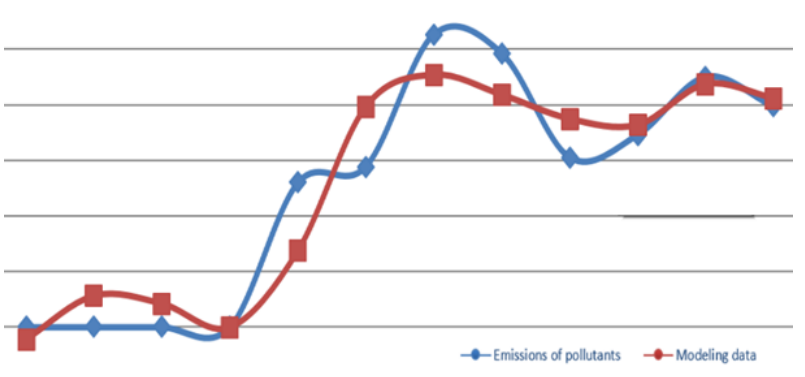

Fig. 4. Dynamics of actual data of the studied indicator "Recycled" and calculated according to the multifactor model.

In the case of multiple correlation, the so-called multicollinearity may be present which is correlation dependence between factors, so it was checked and it was concluded that there was no significant correlation between the selected factors, and therefore all factors could be used to construct the models.

The analysis of the regression statistics has led to the conclusion that all three multifactor models have high correlation and determination coefficients, i.e. they confirm a strong correlation between the selected factors and the performance indicators. The adequacy of the constructed models can also be estimated from the results of the Fisher test, which allows to estimate the significance of linear regression models: in all three multifactor models, this criterion is larger than the table value (2.99), which indicates the approximation of empirical data to the performance indicators, i.e modeling.

The obtained multivariate regression models are as follows:

$$
\begin{gathered}
Y_{1}=89,36329+0,002334 x_{1}+0,002022 x_{2}-0,005 x_{3}- \\
-0,00693 x_{4}-0,00559 x_{5}-0,00086 x_{6} \\
Y_{2}=1883120-38,1355 x_{1}-15,8833 x_{2}+56,38903 x_{3}- \\
-271,267 x_{4}-65,8728 x_{5}-28,0498 x_{6} \\
Y_{3}=392046,3-6,37886 x_{1}-10,1655 x_{2}+19,03229 x_{3}- \\
-55,4992 x_{4}+70,66399 x_{5}-3,893 x_{6}
\end{gathered}
$$

With regard to the first performance indicator (pollutant emissions), it has the greatest impact on the costs of return water treatment and air protection, and the costs of soil protection and rehabilitation reduce emissions. The formation of hazardous waste factor affecting spending on biodiversity conservation and habitat. The third model (hazardous waste disposal) has the greatest impact on the cost of "waste management and conservation of diversity". Increasing the cost of these factors will increase waste disposal.

Figure 4 presents the actual and predicted data from one of the models obtained. 
The obtained dependence equations can be used for predictive calculations. Substituting new values into these equations allows us to obtain the predicted value of a performance indicator.

We have increased all environmental costs by $20 \%$ and, according to the regression model, we have projected a reduction in pollutant emissions up to 16.3 thousand tons (Table 6), which is 4.8 thousand tons less than in the last year.

Table 6. Forecasting the indicators of regression multivariate models.

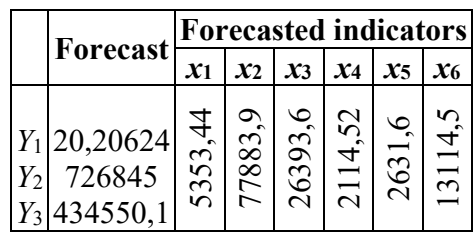

This study points to the need to focus on factors such as environmental costs. The most efficient use of financial and economic resources will allow to reduce the emissions of pollutants.

The next step in the study is the forecast of selected indicators by the methods of predictive extrapolation, which are the most accessible for technical implementation.

When forecasting by extrapolation methods we proceed from the inertia of phenomena (processes) that are studied and predicted [11].

To assess the quality of the forecast results, we will use the actual values of the exogenous variables, that is, the "ex post" method [12]. Table 7 presents the results of the projection of the environmental indicator for the environment "Emissions of pollutants" for 2018 and its comparison with the actual indicator for the same year.

Table 7. Forecasting of the "Pollutant emissions" indicator and checking the quality of the forecast.

\begin{tabular}{|c|c|c|c|c|}
\hline $\begin{array}{c}\text { The } \\
\text { actual } \\
\text { value }\end{array}$ & Forecasting & $\begin{array}{c}\text { Absolute } \\
\text { deviation }\end{array}$ & $\begin{array}{c}\text { Relative } \\
\text { deviation, } \\
\%\end{array}$ & $\begin{array}{c}\text { Forecasting } \\
\text { methods }\end{array}$ \\
\hline \multirow{2}{*}{21,1} & 7,20 & $-13,9$ & $-65,8$ & $\begin{array}{c}\text { Average } \\
\text { absolute gain }\end{array}$ \\
\cline { 2 - 5 } & 15,67 & $-5,4249$ & $-25,7$ & $\begin{array}{c}\text { Average } \\
\text { annual growth } \\
\text { rate }\end{array}$ \\
\cline { 2 - 5 } & 10,36 & $-10,742$ & $-50,9$ & $\begin{array}{c}\text { Method of } \\
\text { fluctuating } \\
\text { average }\end{array}$ \\
\hline
\end{tabular}

As can be seen from the table, all the forecasting methods did not perform very well. The average annual growth rate was the best among simple forecasting methods, it showed the smallest deviation from the actual data $(25.7 \%)$, the worst in this case was the average absolute growth method (65.9\% deviation).

Table 8 and 9 present the results of the forecasting of the "Formation" and "Disposal of Hazardous Waste" values.

As can be seen from Table 8, the formation of hazardous waste tends to increase. But all the prediction methods were inaccurate in this case, since they all have a large error of more than $10 \%$.

Table 8. Hazardous waste generation forecasting and quality assurance.

\begin{tabular}{|c|c|c|c|c|}
\hline $\begin{array}{c}\text { The } \\
\text { actual } \\
\text { value }\end{array}$ & Forecasting & $\begin{array}{c}\text { Absolute } \\
\text { deviation }\end{array}$ & $\begin{array}{c}\text { Relative } \\
\text { deviation, } \\
\text { \% }\end{array}$ & $\begin{array}{c}\text { Forecasting } \\
\text { methods }\end{array}$ \\
\hline \multirow{3}{*}{928151,3} & 1256781,1 & 328629,8 & 35,4 & $\begin{array}{c}\text { Average } \\
\text { absolute gain }\end{array}$ \\
\cline { 2 - 5 } & 1259998,3 & 331847 & 35,7 & $\begin{array}{c}\text { Average } \\
\text { annual } \\
\text { growth rate }\end{array}$ \\
\cline { 2 - 5 } & 1336946,1 & 408794,8 & 44,1 & $\begin{array}{c}\text { Method of } \\
\text { fluctuating } \\
\text { average }\end{array}$ \\
\hline
\end{tabular}

Table 9. Hazardous waste utilization and quality assurance of the forecast.

\begin{tabular}{|c|c|c|c|c|}
\hline $\begin{array}{c}\text { The } \\
\text { actual } \\
\text { value }\end{array}$ & Forecasting & $\begin{array}{c}\text { Absolute } \\
\text { deviation }\end{array}$ & $\begin{array}{c}\text { Relative } \\
\text { deviation, } \\
\text { \% }\end{array}$ & $\begin{array}{c}\text { Forecasting } \\
\text { methods }\end{array}$ \\
\hline \multirow{3}{*}{397027} & 431032,4 & 34005,4 & 8,56 & $\begin{array}{c}\text { Average } \\
\text { absolute gain }\end{array}$ \\
\cline { 2 - 5 } & 432826,3 & 35799,3 & 8,6 & $\begin{array}{c}\text { Average } \\
\text { annual growth } \\
\text { rate }\end{array}$ \\
\cline { 2 - 5 } & 463887,8 & 66860,8 & 16,8 & $\begin{array}{c}\text { Method of } \\
\text { fluctuating } \\
\text { average }\end{array}$ \\
\hline
\end{tabular}

As it can be seen from Table 9, the indicator for the disposal of harmful emissions tends to increase. Two forecasting methods showed an error of deviation from the actual data of less than $10 \%$, and the current average method of more than $10 \%$, i.e. it is not recommended to be used for forecasting.

The reason for the big error is the instability of the dynamic data series. The reason for the deviation from the actual data may be the disadvantages of these methods, namely: incorrectly chosen form of the model, i.e. wrong assumption as a basis for predicting assumptions about the linear nature of the change in time; the wrong accepting of the last level of the dynamic series as the reference level of the series, on which the result of the prediction will depend [13].

It should also be emphasized that these simple extrapolation methods are based on the assumption of a virtually unchanging nature of the flowing process and the absence of significant changes in the state of the external and internal environment of the prediction object, but this is not possible in practice, since the process is constantly influenced by some factors [4].

Let's consider another method of forecasting which is a trend-based extrapolation.

Generally, a trend is determined on the basis of a trend line. To determine the trend, it is enough to build a graph for the values of the studied indicator and based on it to conclude on the nature of their change. The quality of the selected model is judged by the value of the coefficient of determination: the closer it is to one (1), the better the model is. 
Table 10, 11 and 12 show the trend models based on environmental performance indicators. As you can see, some trend lines predict a decrease in the amount of pollutant emissions, but there are also trends that smooth the dynamic series and predict an increase in emissions over the next two years. At the same time, the trend dependencies of the "waste generation" indicator quite accurately reflect the distribution of data and can be used for forecasting for $2019(F)$.

Table 10. Trend models and forecast for the year 2019 as for pollutant emissions.

\begin{tabular}{|l|c|c|c|}
\hline Dependency type & Equation & $\boldsymbol{R}^{\mathbf{2}}$ & $\boldsymbol{F}$ \\
\hline Linear & $Y=-0,5687 x+72,52$ & 0,022 & - \\
\hline $\begin{array}{l}\text { Third degree } \\
\text { polynomial }\end{array}$ & $\begin{array}{c}Y=-0,1129 x^{3}+2,6917 x^{2}- \\
-15,705 x+84,294\end{array}$ & 0,803 & 23,33 \\
\hline $\begin{array}{l}\text { Second degree } \\
\text { polynomial }\end{array}$ & $Y=-0,5252 x^{2}+9,4099 x+39,257$ & 0,425 & 28,45 \\
\hline Logarithmic & $Y=-0,598 \ln (x)+68,325$ & 0,001 & - \\
\hline Exponential & $Y=78,65 e^{-0,024 x}$ & 0,088 & - \\
\hline Degree & $Y=74,426 x^{-0,084}$ & 0,025 & - \\
\hline
\end{tabular}

Table 11. Trending models and forecast for 2019 for hazardous waste generation.

\begin{tabular}{|l|c|c|c|}
\hline Dependency type & Equation & $\boldsymbol{R}^{\mathbf{2}}$ & $\boldsymbol{F}$ \\
\hline Linear & $Y=97262 x-364101$ & 0,62 & 1483877 \\
\hline $\begin{array}{l}\text { Third degree } \\
\text { polynomial }\end{array}$ & $\begin{array}{c}Y=-2327,8 x^{3}+66500 x^{2}- \\
-423670 x+574675\end{array}$ & 0,77 & 1544794,8 \\
\hline $\begin{array}{l}\text { Second degree } \\
\text { polynomial }\end{array}$ & $\begin{array}{c}Y=157,57 x^{2}+94268 x- \\
-354122\end{array}$ & 0,62 & 1493852,8 \\
\hline Logarithmic & $Y=568400 \ln (x)-589401$ & 0,47 & - \\
\hline Exponential & $Y=33,003 e^{0,663 x}$ & 0,81 & 1432456,1 \\
\hline Degree & $Y=5,9511 x^{3,9654}$ & 0,65 & 1443244,7 \\
\hline
\end{tabular}

Table 12. Trend models and forecast for 2019 as for hazardous waste disposal.

\begin{tabular}{|l|c|c|c|}
\hline Dependency type & Equation & $\boldsymbol{R}^{2}$ & $\boldsymbol{F}$ \\
\hline Linear & $Y=32694 x-140168$ & 0,71 & 481018 \\
\hline $\begin{array}{l}\text { Third degree } \\
\text { polynomial }\end{array}$ & $\begin{array}{c}Y=-536,09 x^{3}+16645 x^{2}- \\
-112543 x+160253\end{array}$ & 0,82 & 463037,6 \\
\hline $\begin{array}{l}\text { Second degree } \\
\text { polynomial }\end{array}$ & $Y=1366,1 x^{2}+6737,8 x-53648$ & 0,74 & 57628,3 \\
\hline Logarithmic & $Y=182914 \ln (x)-199424$ & 0,51 & 432556,6 \\
\hline Exponential & $Y=10,899 e^{0,6508 x}$ & 0,78 & 512345,7 \\
\hline Degree & $Y=2,6353 x^{3,76}$ & 0,59 & 447555,2 \\
\hline
\end{tabular}

The coefficient of determination in predicting the "utilized hazardous waste" indicator also showed a value greater than 0.5 , i.e. all trend models can be used for forecasting.

As you can see, only polynomial models approximate the original series of data well, repeating the declines and recessions, but this model gives unacceptable forecast and many observations: the right branch goes up and as it is known, when increasing, $t$ increases indefinitely.

Of course, it is almost impossible to make an adequate prediction with such a model.

In modeling, the question always arises as to how close these models are to the economic reality reflected in the time series, and to what extent the use of these models is justified for the analysis and forecasting of the studied economic phenomenon. Therefore, before making a final prediction on forecast models, it is worth assessing what kind of forecast can be expected from the resulting model in the near future, and whether this forecast can be true [14]. If the model shows the presence of extremes in the near term or an acute change in trends (sharp increase or decrease), it may be worth referring to another trend model.

For further calculation of the forecast, such constructed trend models were used, where the coefficient of determination is the biggest. Since the coefficient of determination shows the degree of change in the performance indicator due to the selected factors, in the situation of trend models - this indicator reflects how clearly the trend is observed in the time series.

Thus, comparing the obtained predicted values for 2019 by the above methods, we can conclude that polynomial trends reflect the trend of real data the most accurately, as well as the methods of regression models gave a good result in forecasting the environmental situation (Table 13). We can observe that different methods gave different models in terms of the quality of forecasts, that is, there is no universal method of forecasting.

Table 13. Comparative characteristics of the obtained forecasting results by different methods.

\begin{tabular}{|l|c|c|c|}
\hline \multirow{2}{*}{ Method } & \multicolumn{3}{|c|}{ Forecasting indicators for 2019 } \\
\cline { 2 - 4 } & $\begin{array}{c}\text { Emissions } \\
\text { of pollu- } \\
\text { tants }\end{array}$ & $\begin{array}{c}\text { Formation } \\
\text { of hazardous } \\
\text { waste }\end{array}$ & $\begin{array}{c}\text { Disposal of } \\
\text { hazardous } \\
\text { waste }\end{array}$ \\
\hline $\begin{array}{l}\text { The method of the } \\
\text { average annual } \\
\text { growth factor }\end{array}$ & 11,32 & 1221568,28 & 416214,23 \\
\hline $\begin{array}{l}\text { The method of } \\
\text { average absolute } \\
\text { growth }\end{array}$ & 6,30 & 1213924,90 & 411963,40 \\
\hline $\begin{array}{l}\text { Forecasting based } \\
\text { on a fluctuating } \\
\text { average }\end{array}$ & 8,17 & 1363963,71 & 490131,25 \\
\hline $\begin{array}{l}\text { Trend Method } \\
\text { (Best Trend } \\
\text { Model) }\end{array}$ & 23,3 & 1432456,1 & 463037,7 \\
\hline $\begin{array}{l}\text { One-factor } \\
\text { regression model }\end{array}$ & 16,26 & - & - \\
\hline $\begin{array}{l}\text { A multifactor } \\
\text { regression model }\end{array}$ & 20,21 & 1726845 & 434550,1 \\
\hline
\end{tabular}

Therefore, comparing the forecasting methods we can conclude that although not always the results obtained can be interpreted as accurate and reliable, but when it is more important to obtain predictive estimates more quickly than their accuracy, or to obtain a model as a guide for future development, which can be edited depending on the influence of other factors, not yet taken into account in this calculation, such models can also be used. Regarding the differences in the prediction results, we can say that these results would be better under stable conditions, and since the forecasting environment in our case is dynamic, it is difficult to calculate the accuracy of the forecasting, as the conditions are constantly changing, and moreover, these methods are short-term forecasting methods [11].

Unfortunately, these models do not identify ways of overcoming the environmental impact of pollutants. The models of forecasting and modeling obtained do not solve 
the problem of environmental protection at the economic level, but investigate the impact of financial costs on environmental protection. The article describes known processes and the economic mechanisms for their prevention are not defined. It is desirable to pay attention to the economic aspects of these processes. The analysis of the projections will allow the implementation of environmentally balanced policies and the protection of natural ecosystems. Modeling enables employees of environmental departments or managers of regional structures to calculate the optimal state of environmental indicators for known economic or regional development factors and to trace the future trend that is required when making management decisions. Thus, the developed models in the region have shown the need to increase the cost of environmental protection, which can reduce harmful emissions and increase waste disposal.

\section{References}

1. L.P. Borisova, V.V. Koval, V.D. Muzhaylo, Functioning and development of the system of resource saving in the conditions of social transformations. Azov Economic Bulletin 3, 23-27 (2017)

2. V.M. Lysyuk, O.E. Volchkov, The urgency of using solid household waste as an energy resource. Economic innovations 64, 48-54 (2017)

3. I.L. Tsymbalyuk, O.A. Gavrilchak. Ecological safety of Ukraine (2011), http://vnumi.blogspot.com/2011/05/blog-post_4854.html. Accessed 29 Sep 2019

4. A. Gorova, A. Pavlychenko, O. Borysovs'ka, The study of ecological state of waste disposal areas of energy and mining companies, in Mining of Mineral Deposits (CRC Press, 2013), pp. 169-171. doi:10.1201/b16354-30

5. N.M. Zaverukha, V.V. Serebriakov, Yu.A. Skyba, Osnovy ekolohii (Karavela, Kyiv, 2019)

6. The Law of Ukraine "On Waste" (Verkhovna Rada of Ukraine Bulletin, 1998, No. 36-37, Article 242; (2002), No. 31, Article 214; (2010), No. 10, Article 107; (2011) 23, Art. 160)

7. O.O. Trush, M.V. Andriyenko, G.A. Lomovskyh, Formation and realization of the common environmental policy of the European Union in the conditions of modern integration processes. State Building 1 (2014)

8. Official site of the State Statistics Service of Ukraine (2020), http://www.ukrstat.gov.ua. Accessed 2 Feb 2020

9. Official site of the Main Department of Statistics in Khmelnytskyi Oblast (2020), http://www.km.ukrstat.gov.ua. Accessed 22 Jan 2020

10. State Statistics Service of Ukraine, Waste generation and management in 2017: Express issue (2017), https://ukrstat.org/en/express/expr2017/05/109w.zip. Accessed 21 Mar 2020
11. V.M. Geyets et al, Models and methods of socioeconomic forecasting (Inzhek, Kharkiv, 2005)

12. V.M. Geyets, T.S. Klebanova, O.I. Chernyak, V.V. Ivanov, N.A. Dubrovina, A.V. Stavitsky, Models and methods of socio-economic forecasting (Inzhek, Kharkiv, 2005)

13. O.V. Malei, A.O. Klyuchka, Concerning the Development of a Modern Waste Management System in Ukraine, in Environmental Management in the General Management System: Proceedings of the Thirteenth Annual All-Ukrainian Scientific Conference, Sumy, April 17-18, 2013, ed. by O.M. Telizhenko (SSU, Sumy, 2013), pp. 91-94

14. A. Antonets, D. Plyatsuk, Analysis of informationanalytical systems development of environmentally dangerous situation modeling. Technology audit and production reserves $\mathbf{6}(2(26))$, 8-12 (2015). doi: $10.15587 / 2312-8372.2015 .56800$ 